\title{
Banking regulations: An examination of the failure \\ of African Bank using Merton's structural model
}

AUTHORS:

Leon B. Sanderson ${ }^{1}$

Eben Maré2

Dawie C.J. de Jongh ${ }^{3}$

\section{AFFILIATIONS:}

${ }^{1}$ Centre for Business

Mathematics and Informatics,

University of the North-West,

Potchefstroom, South Africa

${ }^{2}$ Department of Mathematics and Applied Mathematics, University of Pretoria, Pretoria, South Africa

${ }^{3}$ Centre for Business

Mathematics and Informatics, University of the North-West,

Potchefstroom, South Africa

\section{CORRESPONDENCE TO: Eben Maré}

EMAIL:

eben.mare@up.ac.za

\section{KEYWORDS:}

Merton model; distance-todefault; financial health; analysis; put option

\section{HOW TO CITE:}

Sanderson LB, Maré E, De Jongh DCJ. Banking regulations: An examination of the failure of African Bank using Merton's structural model. S Afr J Sci. 2017;113(7/8), Art. \#a0216, 7 pages. http://dx.doi. org/10.17159/sajs.2017/a0216
The business of banking involves the taking of deposits and the making of loans. Banking balance sheets are typically highly leveraged, with equity capital generally dwarfed by debt capital. Banks are regulated entities; the nature of regulation does not, generally, consider the market prices of the securities issued by a particular bank. In this contribution, we evaluate the capacity of the Merton structural model to provide insight into a bank's financial health in the context of the failure of African Bank in 2014.

\section{African Bank Ltd.}

African Bank Ltd. was placed in curatorship on 10 August 2014. ${ }^{1}$ This occurrence took place against a backdrop of a significant capital raise in 2013 with detailed remedial action undertaken by management. ${ }^{2,3}$ In March ${ }^{4}$ and April $^{5}$ of 2016, a restructured African Bank emerged from curatorship, with significant losses imposed on creditors and shareholders.

The failure of African Bank was a shock to the South African markets and introduced significant systemic risk in the South African financial system. Could this risk have been highlighted at an earlier stage? Was there a way to avoid this outcome?

\section{Banking regulation}

Banking is a highly regulated industry globally. This level of oversight is justified as banks are institutions that take deposits from the public and generally have highly leveraged balance sheets given their capacity to create money via the fractional reserving requirement. Regulation encompasses both supervision of the activities undertaken and monitoring of exposures against prudential guidelines and limits.

Global best practice for supervision, with the US banking industry as a specific example $e^{6,7}$, encompasses both on-site examinations and off-site surveillance. Off-site surveillance provides an ongoing impression of bank performance. On-site examinations are the primary supervisory tool during which banks are assessed across various risk and operational factors. These factors are captured in a so-called CAMELS assessment, that is, capital protection $(C)$, asset quality $(A)$, management competence $(M)$, earnings strength $(E)$, liquidity $(L)$ and, more recently, aspects pertaining to the overall financial system $(S)$. The combination of a given bank's performance across these factors results in a single score or rating being generated for the given bank. ${ }^{7}$ Remedial action, where necessary, across the factors will be communicated to the bank concerned and progress on improvements monitored thereafter. CAMELS type assessments are generally infrequent (certainly no more than once per year), with ongoing off-site surveillance incorporating the modelling of likely changes to these ratings.

The Basel Committee on Banking Supervision provides the global regulatory capital framework for the banking industry. This Committee sets the standards for prudential regulation of banks via risk-based capital measures. ${ }^{8}$ The application of these standards is dependent on information provided by the banks, including the application of the bank's internal models and evaluation of risk. These standards are the primary tool for off-site surveillance.

In practice neither the supervision nor the exposure monitoring undertaken was sufficient to prevent African Bank's woes.

\section{Market prices and bank financial health}

An alternative approach to the evaluation of a bank's financial health is to consider information embedded in the market prices of a company's securities, including both debt and equity instruments. This approach draws heavily on the structural model of Merton ${ }^{9}$. We consider the credit risk (i.e. the likelihood of default) of the bank concerned as a financial put option (i.e. the right, but not the obligation to sell an asset at a fixed price within a predetermined period) on the underlying assets of the firm - the put is struck at the face value of the obligations of the firm. The equity of the bank is a financial call option (the right, but not the obligation to buy an asset at a fixed price within a predetermined period) on the underlying assets of the firm, struck at the face value of the obligations of the firm.

The measure commonly used is the so-called distance-to-default ${ }^{10}$ (DTD), which incorporates the relative leverage of the firm as well as the volatility of its underlying assets. We define default with reference to a fixed time horizon ( 1 year, here and generally) as taking place when the assets of the firm are insufficient to meet the liabilities of the firm. We follow the approach described in Allen and Powell ${ }^{11}$ and model the underlying assets as a stochastic variable and set DTD equal to the difference between the value of a firm's assets and the value of a firm's liabilities, divided by the standard deviation of the firm's assets (over our given time horizon).

Merton ${ }^{12}$ relates equity value and firm asset value as follows:

$E=V N\left(d_{1}\right)-e^{-r T} F N\left(d_{2}\right)$,

Equation 1

where $E$ is the market value of firm equity, $V$ is the value of the firm's assets, $F$ is the face value of the firm's debt (zero coupon), $r$ is the risk free rate, $N$ is the cumulative standard normal distribution function and $T$ is the time horizon. 
Furthermore,

$$
d_{1}=\frac{\ln \left(\frac{V}{F}\right)+\left(r+\sigma^{2} / 2\right) T}{\sigma \sqrt{ } T},
$$

and

$d_{2}=d_{1}-\sigma \sqrt{ } T$,

Equation 3

where $\sigma$ is the annualised standard deviation of asset returns (referred to as volatility).

Market prices are observable for the securities issued by the firm. The asset value and asset volatility of the firm are not directly observable; however, they can be estimated (as discussed in Milne ${ }^{10}$, for example).

Asset value is generally modelled as the sum of debt and equity, and asset volatility can be derived when given a value for underlying equity volatility, i.e.

$\sigma=\left(\frac{V}{E}\right) N\left(d_{1}\right) \sigma_{E}$

Equation 4

where $\sigma_{E}$ is the standard deviation of equity returns.

A more complex estimate of asset value and asset volatility can be derived given prices for two securities issued by the underlying firm that can be valued as options on the underlying assets of the firm (e.g. equity as a call option and debt as a combination of a put option and a risk-free asset).

Distance-to-default (DTD) is usually defined as:

$$
D T D=\frac{\ln \left(\frac{V}{F}\right)+\left(r-\sigma^{2} / 2\right) T}{\sigma \sqrt{ } T}
$$

Equation 5

\section{Data}

African Bank's activities were funded by a combination of debt instruments (both domestic and foreign), preference shares and ordinary shares. All the data we use in this analysis are sourced from Bloomberg, and the raw, unadjusted prices are used for equity.

We consider African Bank Ltd. equity and debt trading data from March 2005 up to August 2014, when the bank was placed into curatorship. We consider so-called price return data only. We consider the curatorship to be a default event.

Our analysis includes the ordinary shares and preference shares listed on the Johannesburg Stock Exchange (JSE) Securities Exchange and the debt instruments issued by African Bank denominated in South African rand and other currencies. We incorporate published balance sheet information in the form of total liabilities in our estimate of total debt. We make use of closing levels for the 1-year swap rate; this term is consistent with the 1-year time horizon applied in the calculation of DTD.

It is important at this stage to highlight significant weaknesses in the underlying data. Whilst the historical data for equity trading activity and preference share trading activity are representative of market activity daily, with two-way pricing and significant volumes executed, the data available on listed debt instruments, both domestic and foreign, are deeply suspect. No measure of actual trading activity is recorded and any price movements observed appear to be with reference to a change in an underlying benchmark only. In effect, the credit spread reflected in the historical prices is more akin to that at the time of issue rather than the prevailing level. We include these data in parts of our analysis below; however, the results are not satisfactory, in that they suggest either that the debt market was oblivious to the events unfolding at African Bank, or that the prices did not reflect market reality. Neither conclusion casts a favourable light on prevailing market practice.

\section{Methodology}

We calculate the DTD on a daily basis, given levels for asset value and asset volatility. We consider data for the period March 2005 to August 2014, where available. We have data for equity value (both ordinary shares and preference shares), realised equity volatility and debt value. We solve for asset value and asset volatility in three distinct ways using the equations above as detailed below.

In assessing the output, we consider a DTD value of one or below to be a significant warning signal as it indicates a high probability of distress in future; in effect, there is a one third chance that the asset value will drop below the value of the debt obligations at the 1-year time horizon.

In the first instance (DTD1), we follow the literature ${ }^{10,12}$ and solve for equity as a call option on the assets struck at a level that takes account of total liabilities and the total quantum of preference shares issued. Balance sheet liabilities are grossed up for the 1-year term at a rate equivalent to the 1-year swap rate plus a spread commensurate with African Bank's funding costs over the period. This spread is set to 250 basis points, which is consistent with the average spread paid by African Bank on its DMTN programme. ${ }^{13,14}$ The grossed-up balance sheet liabilities are denoted as $X$. Preference share nominals are grossed-up for the 1-year term at a rate equivalent to the cash yield on the nominal of the instrument prevailing at the time. The grossed-up preference share nominal is denoted by $Y$. Asset volatility is calculated as per Milne ${ }^{10}$, namely realised equity volatility adjusted for firm leverage.

In the second instance (DTD2), we solve for asset value and asset volatility as two simultaneous equations in two unknowns, where we are given values for equity and preference shares. Equity is valued as above (in DTD1); however, the preference shares are valued as a call-spread (i.e. simultaneous purchase and sale of an equal number of call options that differ only in their strike price) on the assets of the company, where the two strikes are $[X]$ and $[X+Y]$. In effect, the preference share's claim to the assets of the company is limited by the prior claim of the balance sheet liabilities and the nominal outstanding of the preference shares.

In the third instance (DTD3), we solve for asset value and asset volatility as two simultaneous equations in two unknowns, where we are given values for equity and debt. We make use of a single debt instrument and imply a credit spread from the traded price of the debt instrument. This credit spread is then interpreted as a simple 1-year put option on the assets of the company struck at $[X]$.

We make use of the listed ABL10A bond. It was issued in March 2010, carried a coupon of $11.5 \%$, and was due to mature in March 2015. The ABL10A bond was benchmarked on issue against the R201 bond issued by the South African government (coupon of $8.75 \%$ maturing in December 2014). The choice of this bond is motivated by the tenor of the instrument during the period under review. We recognise that the positive yield spread of the ABL10A bond over the relevant government issued benchmark instrument incorporates more than a premium for default risk, including instrument liquidity and investor duration preferences. However, our focus is on the changes in value of equity and debt; and as such we do not adjust the prices of the bond to reflect any other information.

\section{Results}

The results of applying the three distinct methods are shown below. In assessing these results, we wish to understand whether the application of Merton's model provided any forewarning of the future failure of African Bank. In effect, we ask ourselves if the changes in the prices of debt and equity provide insight into the changes in the values of the underlying assets and their volatility.

To illustrate the interaction between asset value, equity value, asset volatility, equity volatility, and DTD, we graph equity value against asset value, and DTD against asset volatility and equity volatility. The general behaviour of equity value and asset value is consistent across DTD1, DTD2 and DTD3; as such we show only the output for DTD1 in Figure 1. We note that equity value changes are generally an amplification of changes in asset value. The general behaviour of DTD against asset volatility and equity volatility varies across DTD1, DTD2 and DTD3. We show the graph of DTD against asset volatility and equity volatility for DTD1 in Figure 2. Our focus is on the values of DTD compared to the levels of asset volatility and equity volatility. We briefly describe the behaviour for each of DTD1, DTD2 and DTD3 and we show the key differences in the three approaches in Table 1, highlighting values as at 


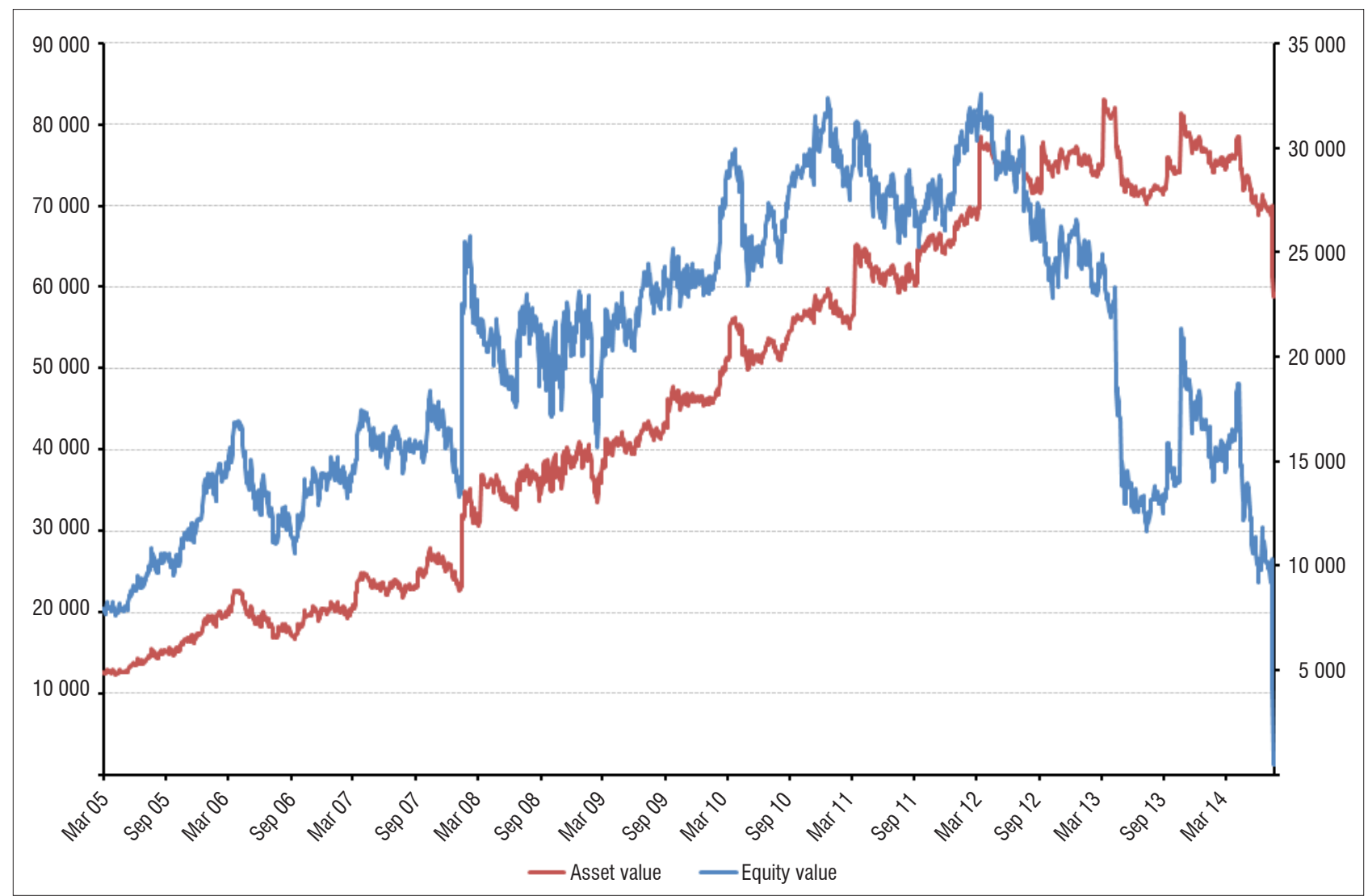

Figure 1: Asset value and equity value under the first distance-to-default scenario (DTD1).

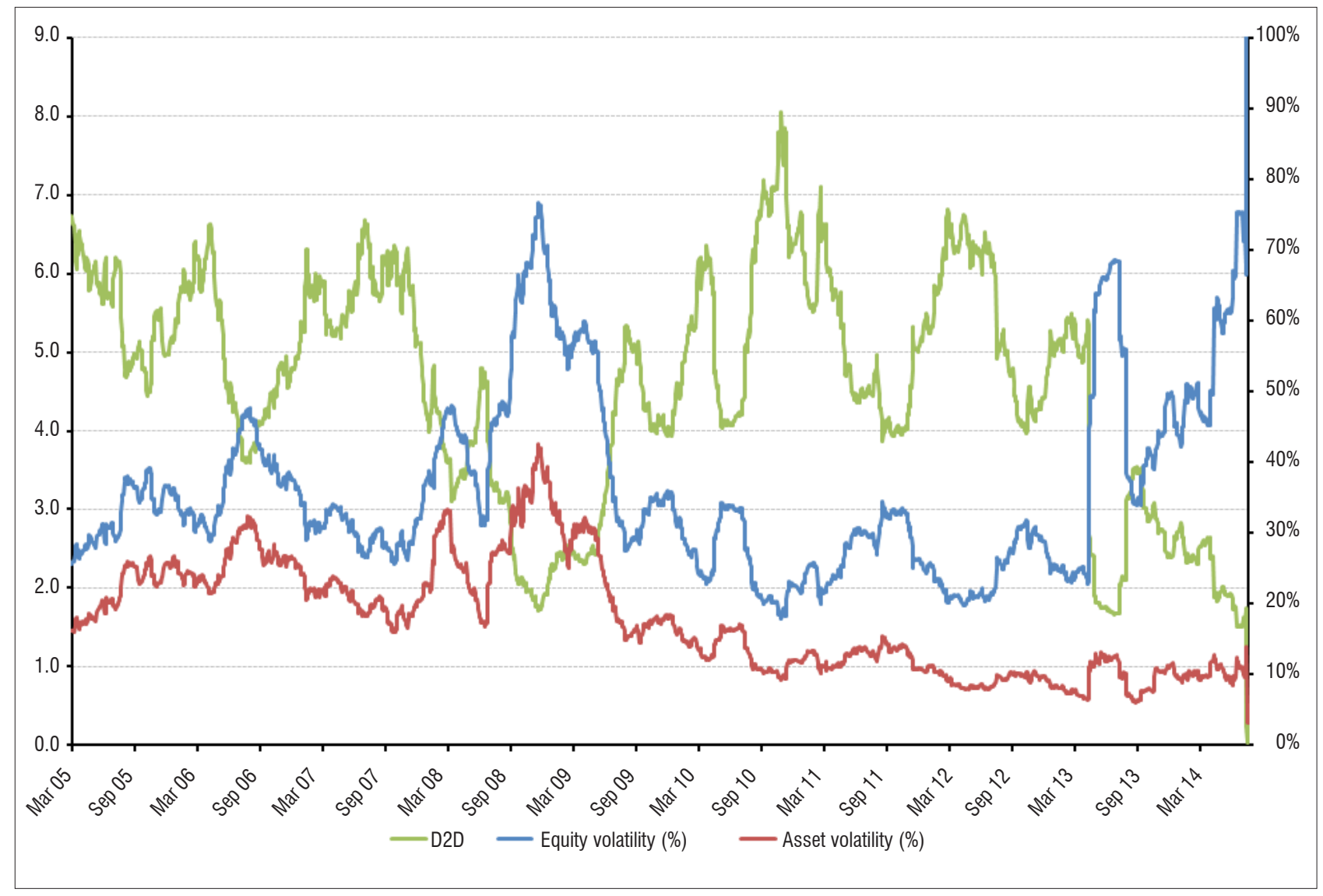

Figure 2: Equity volatility and asset volatility under the first distance-to-default scenario (DTD1). 
the capital raise by African Bank in 2013 and on the days leading up to and including curatorship.

In the case of DTD1, we note that the DTD peaks above eight and declines to zero when the bank is placed in curatorship. DTD is fairly volatile, dropping to two at the peak of the global financial crisis in 2008, but recovering dramatically thereafter. DTD drops below one only in the days prior to default. In the case of DTD1, of particular interest is the behaviour of asset volatility which declines to a level of approximately $10 \%$ by the end of July 2014, in spite of the obvious uncertainty prevailing at the time. Asset volatility drops further as African Bank moves into curatorship. This drop is a direct result of using realised equity volatility to determine asset volatility, where asset volatility is linked to equity volatility by a leverage ratio. In this case, the increase in equity volatility is more than offset by the observed increase in leverage. To be clear, we would expect an increase in asset volatility as a result of the very large observed changes in the underlying asset price.

In the case of DTD2, we note that the DTD declines from a peak of approximately six to close to zero when the bank is placed in curatorship. DTD first drops below one in 2008, in the grips of the global financial crisis, recovers somewhat in 2010 , only to drop below one again in 2012 and remain there until default. The calculated DTD suggests financial stress from the initiation of the global financial crisis all the way through to the bank being placed in curatorship.

The general behaviour of DTD in DTD2 suggests financial weakness much earlier than in DTD1; however, the results are marred by the erratic behaviour of the calculated variables, namely asset volatility and DTD. Calculated asset volatility is in excess of $50 \%$ for much of the period analysed. DTD does not follow the significant improvement in equity value after 2008 and tracks close to one all the way to default. This observation can be ascribed to the somewhat volatile price history of the associated preference shares and our assumption that the price of the preference share is driven primarily by changes in the underlying asset value and asset volatility.

We note that so-called perpetual, non-cumulative, non-participating preference shares as a Tier 1 capital raising exercise for banks in South Africa enjoyed much popularity prior to 2006. These instruments suffered a significant price decline as an asset class (i.e. across all issuing banks) in the period up to 2011 (Figure 3). This decline coincided with the introduction of a dividend tax by the South African Revenue Services. To adjust for this behaviour, we consider a shorter period for DTD2, namely January 2012 to August 2014, and we normalise the price series for the preference shares such that the initial value in January 2012 is set to par. In this instance we note that the DTD declines from a peak above five in January 2012 to below zero just prior to the bank being placed in curatorship. DTD first drops below one in June 2013, around the announcement of the rights issue ${ }^{2}$ in August 2013, and remains there until default. We note that asset volatility in both iterations of DTD2 are higher than those of DTD1, with significant increases observed by the end of 2012; however, they too show a decline in asset volatility as we move towards August 2014 and curatorship.

In the case of DTD3, we consider the period March 2010 to August 2014. We note that the mark-to-market spread over the reference bond declines from a level of approximately 320 basis points at issue to 200 basis points in August 2014 when African Bank is placed in curatorship. In effect, the marked credit spread is lower at default than at issue. There appears to be limited actual trading that results in adjustments to the effective mark-to-market as the spread to the benchmark bond is broadly constant for extended periods of time (Figure 4). As a result, we note that the DTD is just above one in March 2010 and drifts down from May 2013 to be just below zero on default. The observed credit spread and the resultant calculated values for DTD are incongruous with the events unfolding at the time. In the case of DTD3, almost perversely,

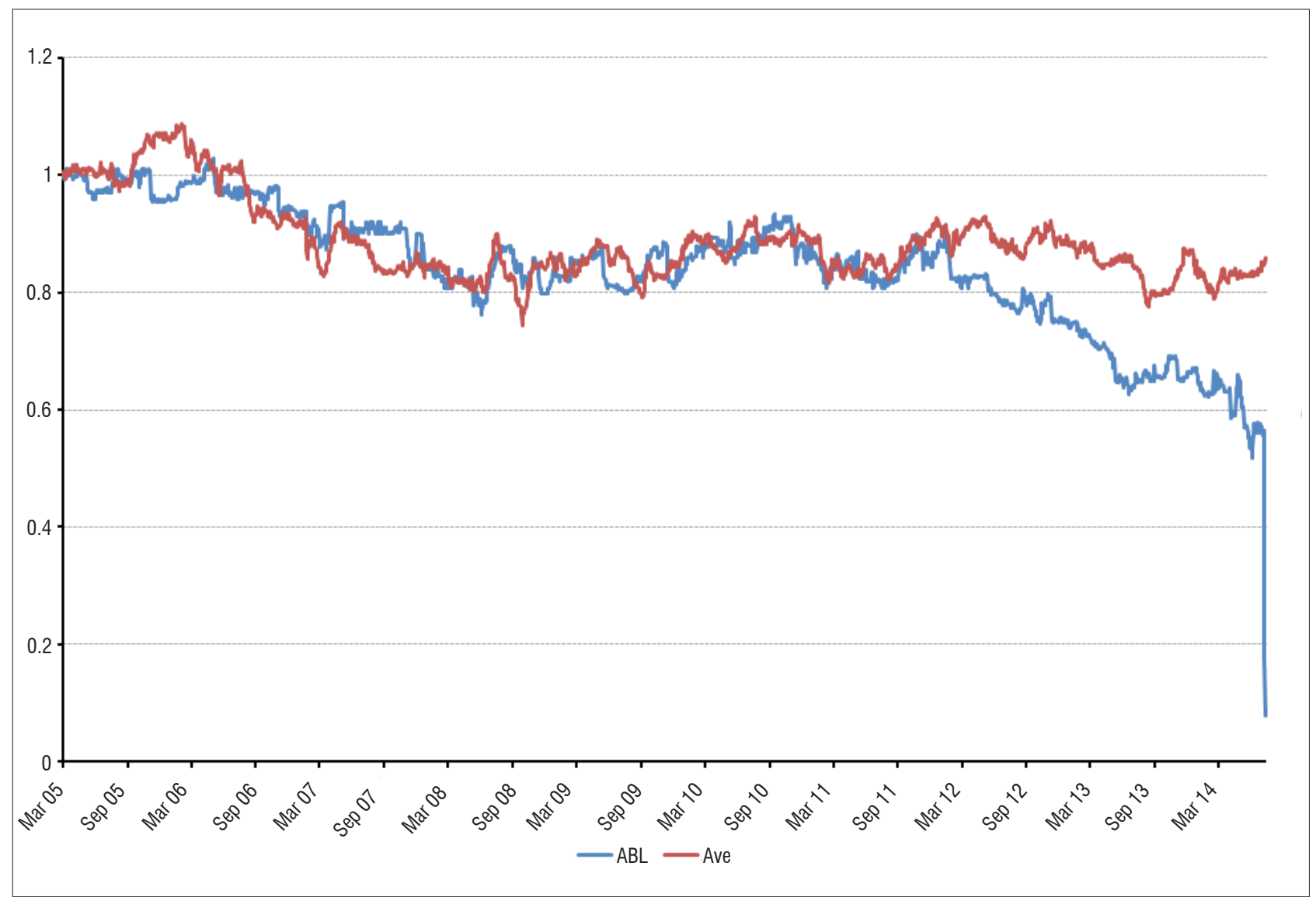

Figure 3: African Bank Ltd. (ABL) preference share versus the average of other bank issues. 


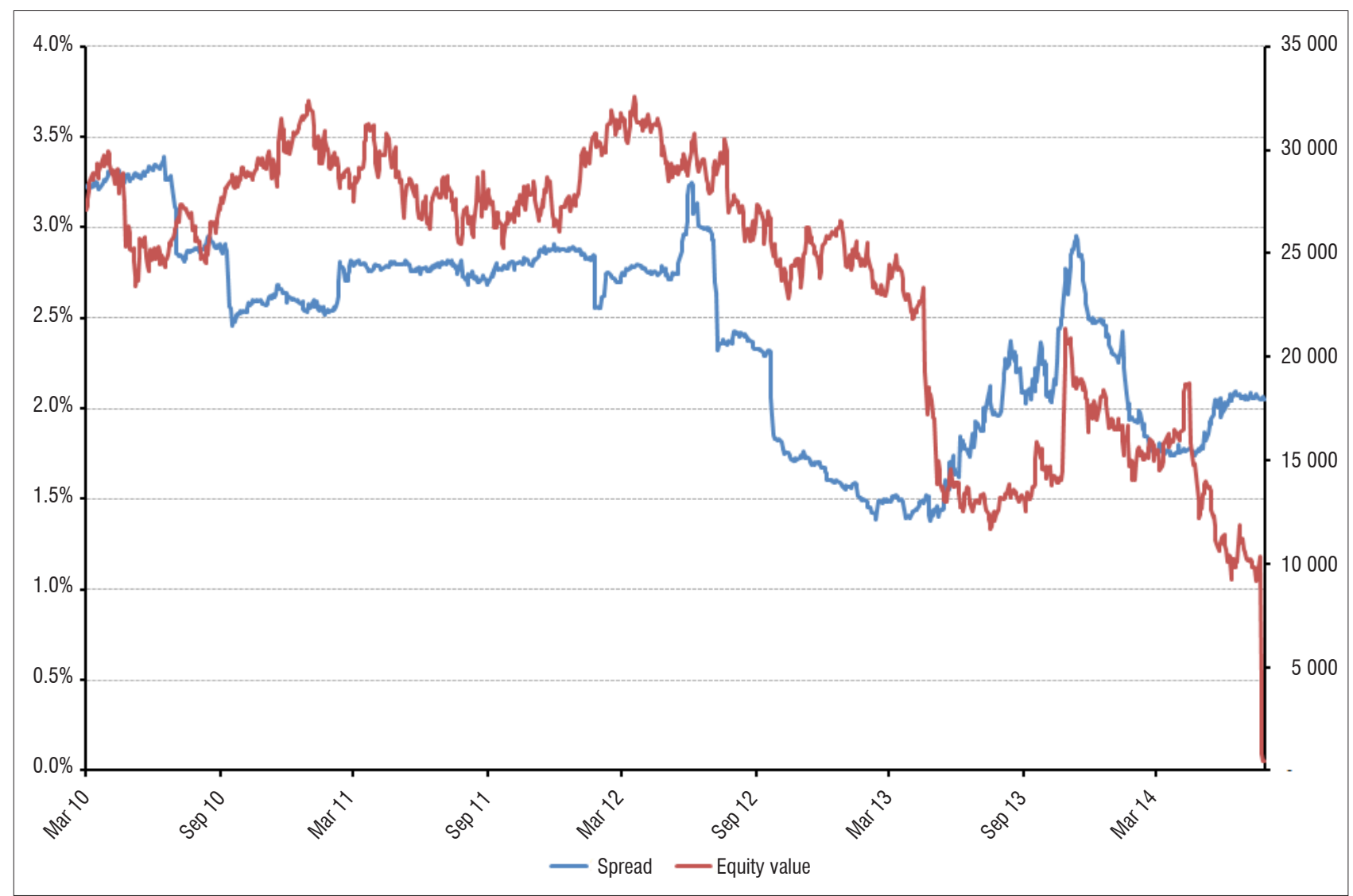

Figure 4: Bond spreads versus equity value.

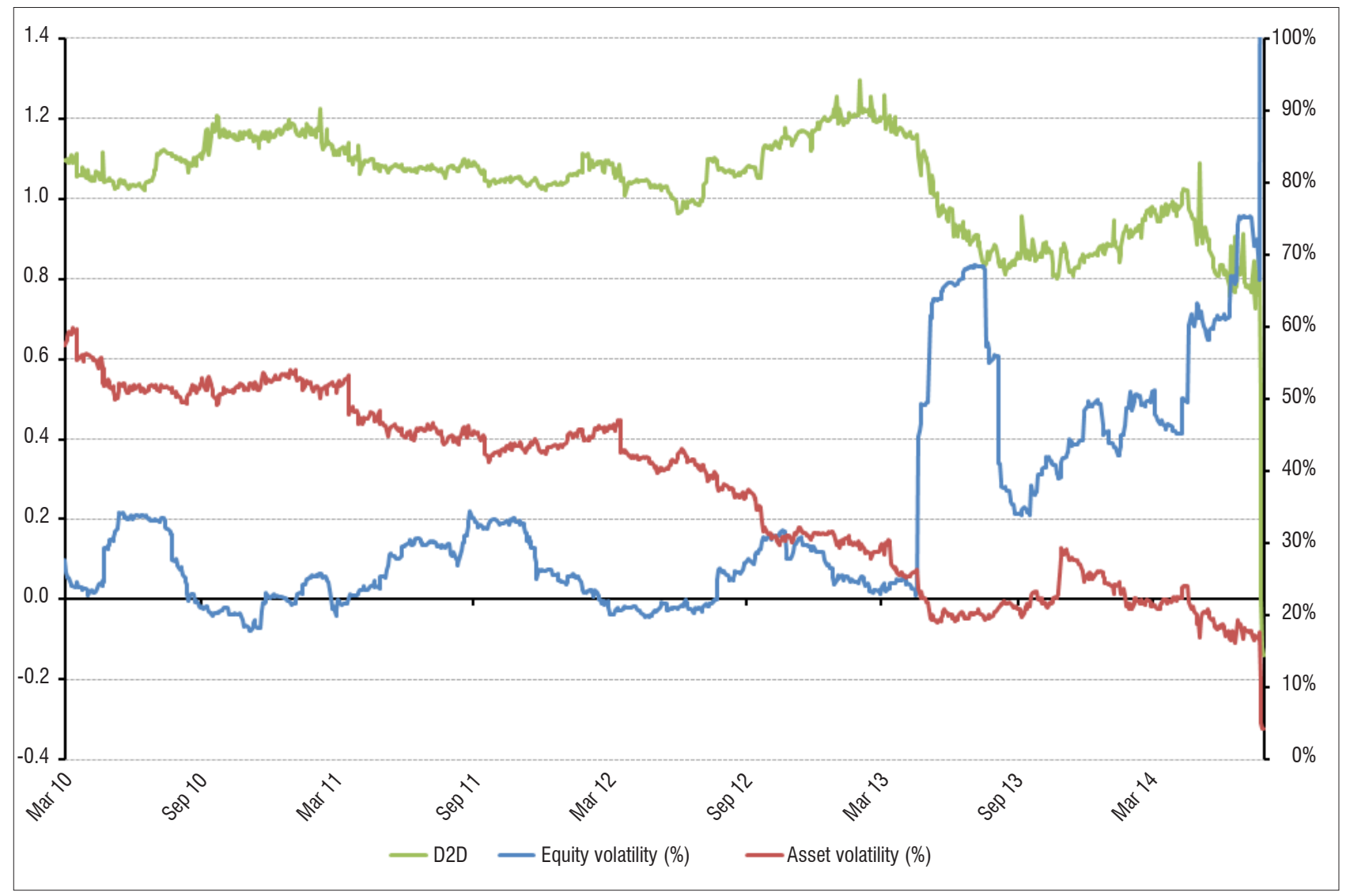

Figure 5: Equity volatility and asset volatility under the third distance-to-default scenario (DTD3). 
Table 1: Equity and asset volatility and distance-to-default (DTD) over time

\begin{tabular}{|c|c|c|c|c|c|c|c|c|c|c|c|}
\hline Date & $\begin{array}{c}30 \mathrm{Dec} \\
2005\end{array}$ & $\begin{array}{c}31 \mathrm{Dec} \\
2007\end{array}$ & $\begin{array}{c}31 \mathrm{Dec} \\
2008\end{array}$ & $\begin{array}{c}31 \text { Dec } \\
2010\end{array}$ & $\begin{array}{c}31 \mathrm{Dec} \\
2012\end{array}$ & $\begin{array}{l}3 \text { May } \\
2013\end{array}$ & $\begin{array}{l}31 \mathrm{Jul} \\
2013\end{array}$ & $\begin{array}{c}31 \mathrm{Dec} \\
2013\end{array}$ & $\begin{array}{l}31 \text { Jul } \\
2014\end{array}$ & $\begin{array}{l}7 \text { Aug } \\
2014\end{array}$ & $\begin{array}{l}8 \text { Aug } \\
2014\end{array}$ \\
\hline \multicolumn{12}{|l|}{ DTD1 } \\
\hline Equity value & $36 \%$ & $32 \%$ & $70 \%$ & $23 \%$ & $27 \%$ & $45 \%$ & $68 \%$ & $80 \%$ & $72 \%$ & $387 \%$ & $397 \%$ \\
\hline Asset value & $28 \%$ & $22 \%$ & $43 \%$ & $14 \%$ & $11 \%$ & $12 \%$ & $12 \%$ & $19 \%$ & $10 \%$ & $5 \%$ & $3 \%$ \\
\hline Distance-to-default & 5.38 & 5.48 & 2.03 & 6.83 & 4.85 & 2.7 & 1.69 & 1.38 & 1.59 & 0.04 & 0.26 \\
\hline \multicolumn{12}{|l|}{ DTD2 } \\
\hline Equity value & $36 \%$ & $32 \%$ & $70 \%$ & $23 \%$ & $27 \%$ & $45 \%$ & $68 \%$ & $80 \%$ & $72 \%$ & $387 \%$ & $397 \%$ \\
\hline Asset value & $74 \%$ & $76 \%$ & $77 \%$ & $64 \%$ & $49 \%$ & $40 \%$ & $34 \%$ & $34 \%$ & $26 \%$ & $14 \%$ & $20 \%$ \\
\hline Distance-to-default & 1.7 & 1.25 & 0.83 & 1.13 & 0.81 & 0.65 & 0.45 & 0.52 & 0.26 & -0.84 & -1.32 \\
\hline \multicolumn{12}{|l|}{ DTD2 (adjusted) } \\
\hline Equity value & & & & & $27 \%$ & $45 \%$ & $68 \%$ & $80 \%$ & $72 \%$ & $387 \%$ & $397 \%$ \\
\hline Asset value & & & & & $31 \%$ & $28 \%$ & $25 \%$ & $24 \%$ & $19 \%$ & $11 \%$ & $17 \%$ \\
\hline Distance-to-default & & & & & 1.6 & 1.2 & 0.85 & 0.97 & 0.58 & -0.7 & -1.22 \\
\hline \multicolumn{12}{|l|}{ DTD3 } \\
\hline Equity value & & & & $23 \%$ & $27 \%$ & $45 \%$ & $68 \%$ & $80 \%$ & $72 \%$ & $387 \%$ & $397 \%$ \\
\hline Asset value & & & & $61 \%$ & $37 \%$ & $28 \%$ & $23 \%$ & $26 \%$ & $17 \%$ & $5 \%$ & $4 \%$ \\
\hline Distance-to-default & & & & 1.23 & 1.27 & 1.18 & 0.91 & 0.87 & 0.76 & 0 & -0.12 \\
\hline
\end{tabular}

the asset volatility is seen to move dramatically lower over the period (Figure 5). This is a direct result of the effective credit spread declining whilst leverage increased and the realised risk in the underlying asset ballooned.

In Table 1, we show equity volatility, asset volatility and DTD for each of the methods applied at regular intervals across a wide term with particular focus on periods of significant change in the capital structure of African Bank.

In all the approaches detailed above, the market data show a wide variation in the financial health of African Bank over the period, covering periods of no stress (with DTD in excess of four) to periods of potential stress (with DTD less than two). The introduction of the African Bank preference share into the analysis shows a wider variation of output.

The recovery of financial health from the stresses associated with the global financial crisis in 2008 proved to be short-lived. The adjusted DTD2 approach shows that the market was highlighting significant risks of financial stress as early as December 2012. The DTD3 approach shows very little variability in the financial health of African Bank over a period of excessive volatility and significant corporate activity. This can be attributed to the static spreads applied to the closing prices of listed African Bank debt which did not reflect the fundamental changes in the financial health of African Bank.

We believe that the analysis above suggests that the consideration of market data provides significant explanatory and predictive output regarding the potential for future bank failures. As is the case with all analysis, the quality of the data is key. Closing prices in the absence of arms-length transactions between market participants do not reflect market prices and should be treated with suspicion.

\section{Conclusion}

The Merton structural model and the DTD measure provide valuable insight into the financial position of a bank. These measures must be incorporated in the regulatory process undertaken on banks and should be an essential component of the toolkit for any financial market professional evaluating the performance and standing of a bank.

Traditional regulation and supervision did not prevent the failure of African Bank. A considered evaluation of market prices offered an early warning signal for impending distress; however, not all market prices are of equal quality and some are categorically suspect. The equity and preference share markets for securities issued by African Bank showed significant weakness and stress in the period leading up to the effective default of the institution. This feature was not mirrored by the closing price data available for the debt instruments issued by African Bank. It is our belief that the closing prices on these instruments did not reflect market conditions at all; as such they offered almost no value to the financial markets. The investment process encompasses a wide range of data evaluation and information assembly, but is undermined by the quality of the data available for debt instruments. The prices available must capture the tradeable market or they should not be made available at all.

\section{References}

1. JSE Securities Exchange Stock Exchange News Service. Suspension of all ABIL and African Bank securities on the exchange operated by the JSE Limited ("JSE") with immediate effect and renewal of cautionary announcement [press release on the Internet]. 2014 August 11 [cited 2017 Apr 24]. Available from: http://trade.imara.co/free/sens/disp_news.phtml?tdate $=2014081108$ $0400 \&$ seq $=11 \&$ scheme $=$ imaraco

2. JSE Securities Exchange Stock Exchange News Service. Abil announces up to $\mathrm{R} 4$ billion capital raise via an underwritten rights issue [statement on the Internet]. 2013 August 05 [cited 2017 Apr 24]. Available from: http://trade. imara.co/free/sens/disp_news.phtml?tdate $=20130805081200 \&$ seq $=5 \&$ sc heme $=$ imaraco

3. JSE Securities Exchange Stock Exchange News Service. Trading update for the financial year ended 30 September 2013 and trading statement [statement on the Internet]. 2013 0ctober 25 [cited 2017 Apr 24]. Available from: http:// trade.imara.co/free/sens/disp_news.phtml?tdate $=20131025090800 \&$ seq $=3 \&$ scheme $=$ imaraco 
4. JSE Securities Exchange Stock Exchange News Service. African Bank restructuring: Ministerial approval obtained and Registrar of Banks approvals granted [statement on the Internet]. 2016 March 15 [cited 2017 Apr 24]. Available from: http://trade.imara.co/free/sens/disp_news.phtml?tdate $=201$ $60315080000 \&$ seq $=2 \&$ scheme $=$ imaraco

5. JSE Securities Exchange Stock Exchange News Service. Confirmation of completion of the African Bank restructuring and quarterly update in terms of Section 1.10(c) of the JSE listings requirements [statement on the Internet]. 2016 April 01 [cited 2017 Apr 24]. Available from: http://trade.imara.co/free/ sens/disp news.phtml?tdate $=20160401081700 \&$ seq $=8 \&$ scheme $=$ imara co

6. Prescott ES. Should bank supervisors disclose information about their banks? FRB Richmond Econ Quart. 2008;94(1):1-16.

7. Gilbert RA, Meyer AP, Vaughan MD. The role of a CAMEL downgrade model in bank surveillance. St. Louis, MO: Federal Reserve Bank of St. Louis; 2000. Available from: https://pdfs.semanticscholar.org/2339/ ebd62c9bd9598a034ee0556427f6544996e6.pdf

8. Basel Committee. The new Basel capital accord. Basel: Bank for International Settlements; 2001.
9. Merton RC. On the pricing of corporate debt: The risk structure of interest rates. J Finance. 1974;29(2):449-470.

10. Milne A. Distance to default and the financial crisis. J Financ Stability. 2014;12:26-36.

11. Allen DE, Powell R. The fluctuating default risk of Australian banks. Aus J Manage. 2012;37(2):297-325.

12. Merton RC. An analytic derivation of the cost of deposit insurance and loan guarantees: An application of modern option pricing theory. J Bank Finance. 1977;30(1):3-11.

13. JSE Securities Exchange Stock Exchange News Service. African bank issues R1 billion of senior unsecured bonds [statement on the Internet]. 2013 June 20 [cited 2017 Apr 24]. Available from: http://trade.imara.co/free/sens/disp_ news. phtml?tdate $=20130620073000 \&$ seq $=2 \&$ scheme $=$ imaraco

14. JSE Securities Exchange Stock Exchange News Service. African Bank raises R2 billion from domestic bond issue [statement on the Internet]. 2013 March 25 [cited 2017 Apr 24]. Available from: http://trade.imar.co/free/sens/disp_ news. phtml ?tdate $=20130325070500 \&$ seq $=3 \&$ scheme $=$ imaraco 